\title{
Bilateral Trade Intensity and Business Cycle Synchronization Nexus: An Analysis from Major Trading Partners of Pakistan
}

\author{
Maryam Batool a , Nabila Asghar ${ }^{\text {b }}$ \\ ${ }^{a}$ PhD Scholar, Department of Economics, University of the Punjab Lahore, Pakistan \\ Email: maryam.pu16@gmail.com \\ ${ }^{\mathrm{b}}$ Associate Professor, Department of Economics and Business Administration, Division of Arts and Social \\ Sciences, University of Education Lahore. Pakistan \\ Email: nabeela.asghar@ue.edu.pk
}

\begin{tabular}{ll}
\hline ARTICLE DETAILS & ABSTRACT \\
\hline History: & $\begin{array}{l}\text { The existing research on the relationship between bilateral trade and } \\
\text { business cycle synchronization (BCS) is limited in the context of }\end{array}$ \\
Available Online June 2021 & $\begin{array}{l}\text { developing countries like Pakistan. Theoretically, bilateral trade can lead } \\
\text { to convergence as well as divergence of business cycles depending upon } \\
\text { prevailing economic conditions in a country. The present study is an }\end{array}$ \\
\hline Keywords: & attempt to explore the relationship between bilateral trade and business \\
Business Cycle Synchronization, & cycle synchronization in Pakistan. For empirical analysis, data of six \\
Trade Intensity, HP-Filter, Panel & major trading partners of Pakistan is collected for the period 1991-2017 \\
Fixed Effect & and multidimensional fixed effect estimation technique has been used. \\
& The results of the study show that bilateral trade has significant and \\
JEL Classification: & $\begin{array}{l}\text { positive impact on BCS. The coordination of fiscal and monetary policies } \\
\text { appears to be significant determinants of GDP synchronization. These }\end{array}$ \\
E36, F40, F44 & $\begin{array}{l}\text { results have strong implications for policymakers and practitioners for } \\
\text { formulating and implementing policies for Pakistan to get the maximum }\end{array}$ \\
DOI: 10.47067/reads.v7i2.353 & benefits of BCS.
\end{tabular}

(C) 2021 The authors. Published by SPCRD Global Publishing. This is an open access article under the Creative Commons Attribution-

NonCommercial 4.0

Corresponding author's email address: nabeela.asghar@ue.edu.pk

\section{Introduction}

The research work on the relationship between bilateral trade and business cycle synchronization (BCS) started in 1961 when Mundell presented a theory on optimal currency areas. The theory states that the formation of a monetary union may generate massive benefits for participating countries and these benefits depend on higher trade linkages, more synchronized business cycles and easy mobility of labour. But the research work conducted by Frankel and Rose (1998) added a new dimension in this field of research. They disclosed that the two most valued criteria trade integration and business cycle synchronization are related to each other. Afterward, several studies have been conducted to check and to add new impetus in this relationship (for example; see, Shin and Wang. 2003, Chiquiar and Ramos-Francia, 2004, Calderón et al., 2007, Inklaar et al.,2008). These studies 


\section{Review of Economics and Development Studies, Vol. 7 (2) 2021, 231-242}

validate that trade integration leads to more synchronized business cycles. Over the past few decades, bilateral trade flows among countries have increased rapidly. The diversity in natural resources and benefits of specialization are the major root cause of trade. Over the years, globalization and removal of trade barriers along with lower transportation cost have boosted the inter-dependence of countries.

Presently, it has been observed that free trade not only gives benefits to all trading nations but also have increased their overall wellbeing. Some studies have advocated that enhanced trade results in higher growth (see, for example, Frankel and Romer, 1999). Furthermore, it has been observed that an increase in economic growth exerts a positive impact on the economy of trading partners as higherincome often leads to higher demand for imported commodities which causes an increase in exports of trading partners. This leads to an increase in income of trading partners and this cycle of trade will keep on benefiting the trading partners. Thus, economic integration in the form of enhanced bilateral trade improves the growth of the region and helps the trading partners to be in a similar phase of the business cycle.

Bilateral trade refers to the sum of imports and exports normalized by GDP or total trade and is considered as the most important determinant of business cycle co-movements. However, theoretically this relation is vague. The enhanced trade can lead to convergence as well as divergence of business cycles as increased trade can affect output movements in several ways. If trade mainly occurs as discussed by Heckscher-Ohlin and David Ricardo, then increased trade may result in a dissimilar industrial structure and in this situation, business cycles of countries may diverge. While, on the other hand, if larger proportion of trade is in the form of intra-industry trade which may result in a symmetric industrial structure and more synchronized movement of the business cycles. Furthermore, in case of consumption-oriented trading countries an increase in trade may increase the GDP raising the demand for imports and exports of the trading partners.

The research work conducted on the relationship between bilateral trade and BCS show that countries may get involve in higher bonding of trade relations, which may lead them toward a similar phase of the business cycle. Thus, trading partners play a significant role in the business cycle fluctuations in an economy. Furthermore, similar monetary and fiscal policies may result in symmetric shocks to the economy which may lead them toward an increase in BCS. Keeping it in view, the present study has included the policy channels by computing two variables as proxies of fiscal and monetary policies. Fiscal policy coordination indicates that countries will adopt similar policies if they have a similar ratio of budget deficit to GDP. As a result, their growth pattern may become similar and their business cycles will converge.

The main objective of this study is to analyze whether trade channel along with other channels are helpful in coordinating BCS of Pakistan and its trading partners or not.

In Table 1, average values of BCS and bilateral trade are presented. The sample period 1991-2017 is divided into three sub-sample periods of nine years each from 1991-98, 2000-o8 and 2009-17. The average of each period helps in understanding the behaviour of variables during that period. 
Review of Economics and Development Studies, Vol. 7 (2) 2021, 231-242

Table 1: Averages Measure of Business Cycle Synchronization and Bilateral Trade in sub-samples

\begin{tabular}{|c|c|c|c|c|}
\hline $\begin{array}{c}\text { Country \& } \\
\text { Period }\end{array}$ & $\begin{array}{l}\text { BCS (Hodrick- } \\
\text { Prescott Filter) }\end{array}$ & $\begin{array}{l}\text { Trade Intensity } \\
\text { (Export only) }\end{array}$ & $\begin{array}{l}\text { Trade Intensity } \\
\text { (Import data) }\end{array}$ & $\begin{array}{c}\text { Trade Intensity } \\
\text { (Export }+ \\
\text { Import) }\end{array}$ \\
\hline \multicolumn{5}{|l|}{ Bangladesh } \\
\hline 1991-99 & 0.0240 & 0.0014 & 0.0045 & 0.0031 \\
\hline 2000-08 & 0.4693 & 0.0011 & 0.0038 & 0.0026 \\
\hline 2009-17 & 0.3063 & 0.0011 & 0.0038 & 0.0027 \\
\hline \multicolumn{5}{|l|}{ China } \\
\hline 1991-99 & -0.1445 & 0.0080 & 0.0039 & 0.0058 \\
\hline $2000-08$ & 0.5022 & 0.0174 & 0.0070 & 0.0114 \\
\hline $2009-17$ & 0.3397 & 0.0241 & 0.0092 & 0.0164 \\
\hline \multicolumn{5}{|l|}{ India } \\
\hline 1991-99 & 0.1789 & 0.0040 & 0.0020 & 0.0056 \\
\hline 2000-08 & 0.4637 & 0.0058 & 0.0023 & 0.0076 \\
\hline $2009-17$ & 0.2733 & 0.0083 & 0.0037 & 0.0104 \\
\hline \multicolumn{5}{|l|}{ Iran } \\
\hline 1991-99 & 0.0128 & 0.0072 & 0.0022 & 0.0029 \\
\hline $2000-08$ & 0.2817 & 0.0073 & 0.0022 & 0.0041 \\
\hline $2009-17$ & 0.2498 & 0.0194 & 0.0035 & 0.0058 \\
\hline \multicolumn{5}{|l|}{ Pakistan } \\
\hline 1991-99 & 0.0104 & 0.0042 & 0.0030 & 0.0034 \\
\hline $2000-08$ & 0.5797 & 0.0039 & 0.0030 & 0.0031 \\
\hline $2009-17$ & 0.0384 & 0.0047 & 0.0026 & 0.0032 \\
\hline \multicolumn{5}{|l|}{ Sri Lanka } \\
\hline 1991-99 & -0.0836 & 0.0015 & 0.0039 & 0.0027 \\
\hline $2000-08$ & 0.5361 & 0.0017 & 0.0051 & 0.0032 \\
\hline 2009-17 & -0.0192 & 0.0019 & 0.0034 & 0.0026 \\
\hline \multicolumn{5}{|l|}{ United States } \\
\hline 1991-99 & 0.0351 & 0.0038 & 0.0114 & 0.0080 \\
\hline 2000-08 & 0.6142 & 0.0056 & 0.0189 & 0.0134 \\
\hline $2009-17$ & 0.1093 & 0.0077 & 0.0221 & 0.0154 \\
\hline
\end{tabular}

In the first time period, the business cycle synchronization is low among all countries. However, all countries show a tremendous increase in BCS during second period, which decreases again in 200917. The situation is worst in Sri Lanka as its BCS average is negative in the third period. Overall the GDP synchronization in Pakistan, Sri Lanka and the United States show the highest fluctuations over the three periods.

The trade intensity measures show a positive trend over sub-sample periods. Bangladesh indicates a small decrease in trade intensity. China shows a massive improvement in its output correlation as well as in all three measures of bilateral trade. During the second sub-sample period, the GDP synchronization of China has increased by more than two-folds and its bilateral trade has also doubled. The bilateral trade of India has shown a rising trend but their business cycle synchronization has fluctuated over periods. Business cycle co-movement of India improves in second periods but it decreases again in the third period. Pakistan's GDP synchronization faces a massive decrease in the third period but still it has improved relative to the first period. Trade intensity of Pakistan shows 


\section{Review of Economics and Development Studies, Vol. 7 (2) 2021, 231-242}

mixed behaviour during the selected time. The United States shows a strong improvement in synchronization of its business cycle during the second period and a relatively low but a decrease in the third period. Bilateral trade of the U.S. shows constant improvement. The results reveal that all the countries included in the sample have shown higher trade linkages which enhanced synchronization of business cycles. It is a positive sign which indicates the significance of this relationship.

\section{Review of Literature}

Frankel and Rose (1998) analyzed the co-movement of business cycles using data of 20 industrial countries from 1959 to 1993. The study found the relationship between bilateral trade among trading partners and the correlation of their business cycles. The study concluded that more bilateral trade resulted in more synchronized business cycles and the countries with less synchronization among them were likely to be more synchronized after joining the common monetary union.

Barrious and Lucio (2003) provided evidence on the existence of synchronization of regional business cycles. The study used quarterly data from 1988-1998 and annual data for the period 19751998 for Iberian and European regions. The study used GMM for estimation purpose and pointed out that integration of EU had affected the co-movement of Iberian regional cycles positively. The results revealed that different frequencies of data resulted in a difference in estimates. The study concluded that the size of the economy and industrial structure played a key role in affecting economic cofluctuations.

Gruben et al. (2002) attempted to investigate the findings of Frankel and Rose (1998) regarding the higher trade flows which resulted in greater synchronization of business cycles. The main objective of this study was to observe the validity of the instruments used by Frankel and Rose (1998). The study claimed that Frankel and Rose (1998) had used inappropriate method as their instruments were overestimated. However, the authors pointed out that their results were still in line with Frankel and Rose (1998).

Artis and Siebert (2003) tried to analyze the existence of European business cycles. The study used quarterly data of 23 countries for the period 1970-2001 and employed HP-filter to separate cyclical components from GDP data. The results revealed that the European business cycle did not exist. The study concluded that higher globalization resulted in more synchronized world business cycles.

Shin and Wang (2003) analyzed the impact of growing bilateral trade on the GDP co-movements of 12 Asian economies. Using panel fixed effect model and data for the period 1976-97, the results of the study show that increasing intra-industry trade or total trade could be more effective than interindustry trade in synchronizing business cycles. The positive correlation indicated better prospects of unified currency in the region. The study concluded that the cost of entering a monetary union could be heavily reduced through intra-industry trade which had a higher ratio in the trade of the region.

Barrios et al. (2003) attempted to analyze the patterns and determinants of UK regions and the Euro area. The study used a sample of six Euro Area Countries and 11 UK regions from 1966 to 1997. The findings of the study indicated that business cycles of the UK and Eurozone were dissimilar and internal business cycles of both the UK and Eurozone were highly correlated.

Imbs (2004) attempted to explore the important determinants of GDP co-movements using a simultaneous equation model. The results of the study verified that trade had a significant and positive impact on GDP co-movements as explained by other studies on the subject matter. The study pointed 


\section{Review of Economics and Development Studies, Vol. 7 (2) 2021, 231-242}

out that specialization intensified GDP co-movements along with financial integration.

Böwer and Guillemineau (2006) used the sample of 12 member countries of Euro Area from 1980 to 2004. This study checked the determinants of GDP co-movements in Eurozone using extreme bound-test. The results show that single currency may increase both bilateral trade intensity and intraindusry trade which, in turn, increases the synchronization of business cycles among Eurozone countries.

Camacho and Quiros (2006) formed a new framework based on multivariate Markov-switching procedures for observing the GDP comovements as this approach has shown better results than traditional approaches in the literature. The simulation results revealed that the univariate approach generated lower values of GDP co-fluctuations. The study concluded that G7 countries belonged to Eurozone had more correlated business cycles than other countries and the same was also true for English-speaking G7 countries.

Kose and Yi (2006) investigated whether standard international business cycles could validate the positive relationship between bilateral trade GDP co-movements or not. Following the methodology of Frankel and Rose (1998) and using the data of 21 OECD countries from 1970-2000, three-country models were formulated for simulating the results of complete asset market and financial autarky. The study concluded that trade intencified the business cycle synchronization in both market sitations.

Calderón et al. (2007) used the data of 147 countries to analyze the effect of bilateral trade on output synchronization. The study found that increased trade resulted in higher co-movements of business cycles in both industrial and developing countries. The only difference was that in developing countries the business cycle correlation was smaller as compared to industrial countries.

Xing and Abbott (2007) investigated the impact of trade, specialization and financial integration on GDP co-fluctuations. The study verified the existence of a significant relationship between trade, specialization and finance and pointed out that bilateral trade intensity and industrial structure had a positive and significant influence on business cycle synchronization.

Inklaar et al. (2008) attempted to explore the relationship between trade intensity and GDP comovements among 21 OECD countries during 1970-2003. They constructed a multi-variable model to examine the effects of specialization on GDP co-movements using similar policy along with bilateral trade. They verified that enhanced trade helped in co-movements of business cycles but its effect is smaller than as mentioned in previous studies. The study concluded that industrial specialization and coordination of monetary and fiscal policies had positive impact on business cycles.

Rana et al. (2012) tried to extend the research work of Shin and Wang (2003) through improving business cycle specification. They claimed that intra-industry trade was the major force in deriving the business cycles towards co-movements in East Asia and Europe. This study unveiled that the trade intensity had a strong impact on GDP synchronization in both regions. The study recommended that East Asian countries should strengthen the coordination of economic policies to fully capture the benefits like Europe.

Gouveia and Correia (2013) examined the relationship between trade integration and GDP comovements in the Euro area with focus on Southern European countries. The study pointed out that the GDP co-movements appeared due to increased trade and the trade imbalances had increased after 
existence of EMU trade strongly intensified cyclical correlation.

Misztal (2013) attempted to observe the influence of international trade on GDP co-movements in the Eurozone, EU, and Poland. The results of the study showed that an increase in trade did not necessarily lead to greater synchronization, which depends on the structure of trade rather than the intensity of trade. Further, intra-industry trade had appeared as the main source of co-movements.

Antonakakis and Tondl (2014) attempted to explore the additional factors and channels like market integration and coordinated economic policies along with bilateral trade that triggered output co-movements in the EU. The study used data from 1995-2012, to explore the direct and indirect channels. The findings of the study showed that trade and FDI both had a positive effect on business cycles co-fluctuations in the EU and the increased specialization did not harm the co-movements of business cycles. Furthermore, income disparities and less synchronized fiscal policies along with exchange rate fluctuations hindered output co-movements. The study suggested that coordination in economic policies is necessary to have an effective monetary union.

Duval et al. (2014) explored the relationship between trade intensity and GDP synchronization. They used value-added trade of 63 countries for the period 1995-2012 and claimed that this data would provide better results than gross trade data. The results of the study revealed that trade intensity increased the synchronization of business cycles and this impact had become stronger during crisis times.

Saiki and Kim (2014) attempted to link the business cycle with trade integration. Their major contribution was introducing Vertical Intra-industry trade. Using data from Eurozone and East Asia for the period 1970-2011, the results showed that output synchronization had been increasing over time in Eurozone and Asia but synchronization progressed faster in East Asia. The study concluded that vertical intra-industry trade had unambiguously increased output movements in East Asia but not in Eurozone. Furthermore, the adaptation of the Euro had increased GDP synchronization and the impact of bilateral trade intensity was ambiguous on the business cycle.

The review of previous studies revealed that the relationship between bi-lateral trade intensity and BCS is different in different countries. The research work on Pakistan economy is very limited which brings up the need for analysing the crucial relationship between bi-lateral intensity and BCS as it may provide guidelines to the policy makers to formulate effective policies.

\section{Data and Methodology}

The main focus of this study is to analyze the impact of bilateral trade intensity on business cycle correlation using panel data for the period 1991 to 2017. The data of related variables have been collected from renowned websites World Development Indicators (WDI), International Monetary Fund (IMF), and United Nation Conference on Trade and Development (UNCTAD). For analysis purpose, a multidimensional panel model is formed in which seven countries namely Bangladesh, China, India, Iran, Pakistan, Sri Lanka, and the United States are included.

Following Shin and Wang (2003), the sample period is divided into three sub-periods of nine years each from 1991 to 1999,2000 to 2008 and 2009 to 2017 for analysis purpose.

\subsection{Model Specification}

Considering the nature of analysis, a three-dimensional panel model having two cross-sectional 
Review of Economics and Development Studies, Vol. 7 (2) 2021, 231-242

dimensions and one time-series dimension is used for estimation purpose and each model uses a different measure of bilateral trade.

Model 1:

$$
B C S(i, j)_{\tau}=\alpha+\alpha_{1} B T I x(i, j)_{\tau}+\alpha_{2} F P(i, j)_{\tau}+\alpha_{3} M P(i, j)_{\tau}+\alpha_{4} E X V(i, j)_{\tau}+\alpha_{5} I S(i, j)_{\tau}+\varepsilon_{i j t}
$$

Model 2:

$$
B C S(i, j)_{\tau}=\alpha+\alpha_{1} B T \operatorname{Im}(i, j)_{\tau}+\alpha_{2} F P(i, j)_{\tau}+\alpha_{3} M P(i, j)_{\tau}+\alpha_{4} E X V(i, j)_{\tau}+\alpha_{5} I S(i, j)_{\tau}+\varepsilon_{i j t}
$$

Model 3:

$$
B C S(i, j)_{\tau}=\alpha+\alpha_{1} B T I t(i, j)_{\tau}+\alpha_{2} F P(i, j)_{\tau}+\alpha_{3} M P(i, j)_{\tau}+\alpha_{4} E X V(i, j)_{\tau}+\alpha_{5} I S(i, j)_{\tau}+\varepsilon_{i j t}
$$

Where, $B C S(i, j)_{\tau}$ is the correlation of business cycles between country $i$ and $j$ during $\tau$ period. $B \operatorname{BIx}(i, j)_{\tau}$ is bilateral trade intensity based on exports, $B \operatorname{Im}(i, j)_{\tau}$ is bilateral trade intensity based on imports and $B \operatorname{TIt}(i, j)_{\tau}$ is bilateral trade intensity based on exports and imports. $F P(i, j)_{\tau}$ is fiscal policy correlation and $M P(i, j)_{\tau}$ is the monetary policy correlation. $E X V(i, j)_{\tau}$ measures the volatility of exchange rate between trading partners and $I S(i, j)_{\tau}$ measures the similarity of industrial structure between $\mathrm{i}$ country and $\mathrm{j}$ country during $\tau$ period.

For measuring BCS, first of all, data of real GDP in US\$ is collected from WDI and HP-filter is used to obtain business cycle components. Then the correlation of these cyclical components is calculated to measure the value of business cycle synchronization.

$$
B C S_{i j \tau}=\operatorname{Corr}\left(c_{i}, c_{j}\right)_{\tau}
$$

Following Frankel and Rose (1998) three measures of Bilateral trade intensity are used i.e. $\operatorname{BTIx}(i, j)_{\tau}, \operatorname{BTIm}(i, j)_{\tau}$ and BTIt $(i, j)_{\tau}$ in analysis. First measure BTIx $(i, j)_{\tau}$ uses export data only while $B \operatorname{BTm}(\mathrm{i}, \mathrm{j})_{\tau}$ uses import data only and BTIt $(\mathrm{i}, \mathrm{j})_{\tau}$ uses both import and export data.

$$
\begin{gathered}
B \operatorname{BIx}(i, j)_{\tau}=\frac{x(i, j, t)}{X(i, t)+X(j, t)} \\
\operatorname{BTIm}(i, j)_{\tau}=\frac{m(i, j, t)}{M(i, t)+M(j, t)} \\
\operatorname{BTIt}(i, j)_{\tau}=\frac{x(i, j, t)+m(i, j, t)}{X(i, t)+M(i, t)+X(j, t)+M(j, t)}
\end{gathered}
$$

A higher value of any of these indexes indicates greater trade intensity between country $\mathrm{i}$ and country j.

Fiscal policy is proxied by the ratio of budget deficit to GDP between countries.

$$
\begin{aligned}
& F P(i, t)=\frac{|B D(i, t)|}{\operatorname{GDP}(i, t)} \\
& F P(j, t)=\frac{|B D(j, t)|}{G D P(j, t)}
\end{aligned}
$$

Using the simple correlation between the fiscal policy value of country $\mathrm{i}$ and $\mathrm{j}$ is calculated. 


$$
\text { FPCij } \tau=\operatorname{Corr}(\text { FPit, FPjt) } \tau
$$

Monetary policy is proxied by the annual growth rate of money supply. Data is collected from WDI and correlations between these growth rates are computed.

$$
M P C_{i j \tau}=\operatorname{Corr}\left(M P_{i t}, M P_{j t}\right)_{\tau}
$$

Exchange rate variability is measured following Antonakakis and Tondl (2014). Official exchange rate data from WDI is used to compute this variable. Then, bilateral exchange rates are derived which are used to compute exchange rate variability.

$$
E X C H_{i j \tau}=S T D E V\left[d\left(\ln \left(\operatorname{biex}_{i j}\right)\right)\right]_{\tau}
$$

Where Biexij is the bilateral exchange rate between country $\mathrm{i}$ and $\mathrm{j}$.

Following Imbs (2004) and Xing and Abbott (2007) an industrial similarity index is formed. For measuring this variable, the GDP value-added of six industries namely, agriculture, mining, construction, wholesale, transportations and other activities have been used. Data is collected from UNCTAD.

$$
\mathrm{IS}(\mathrm{ijt})=\ln \left(\frac{1}{\mathrm{~T}} \sum_{\mathrm{t}} \sum_{\mathrm{n}}^{\mathrm{N}}|\mathrm{IS}(\mathrm{ni})-\mathrm{IS}(\mathrm{nj})|\right)
$$

This index is expected to have a negative value because its lower value represents more similar industrial structures. It means that the negative value of this index means higher synchronization of business cycles.

\section{Result and Interpretations}

\subsection{HP-Filter Results}

The estimations begin with the use of HP-filter to detrend the real GDP of all the countries included in the model. HP-filter converts GDP series into two parts namely, trend and cycle. Trend component shows the long-run trend of GDP series while cycle shows the short-run fluctuations over time that represent a business cycle. Both trend and cycle depend on the value of lambda $(\lambda)$ used in HP-filter. As this study uses annual data the value of $\lambda$ equals to 6.25 is used in econometric analysis (For details, see Ravn and Uhlig, 2002). The cyclical portion of GDP of all the countries is shown in following diagrams. 


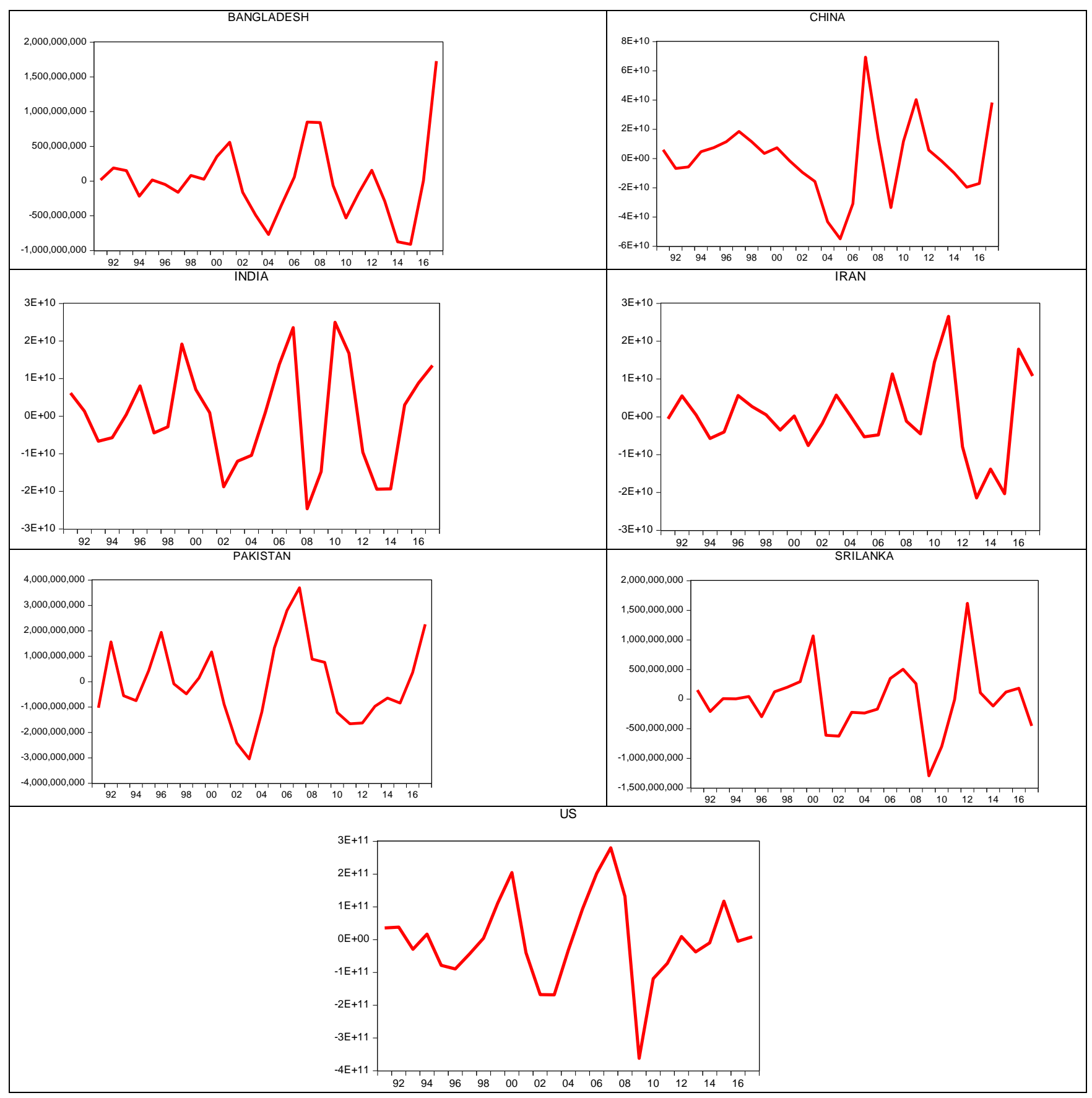

\section{Figure 1: Results of HP-filter}

The cyclical portion of GDP captured by HP-filter shows the fluctuation of GDP over the considered period. Almost all the countries have experienced heavy fluctuations during 2008 due to the global financial crisis. Bangladesh faces a heavy decline in GDP during 2004 due to natural calamities. Their economy improved over time but faces severe decline during 2015. China also faces a decline in GDP in 2005 but massive exports and heavy investment has boosted its economy in coming years. India and Pakistan both face continuous ups and downs in their GDP. While the economy of Iran has been heavily affected due to economic sanctions. Being an economic super power, the United States had faced problems particularly during the global financial crisis. 
Review of Economics and Development Studies, Vol. 7 (2) 2021, 231-242

Results of Panel Estimation

The results of all the three models are presented in Table 2.

Table 2: $\quad$ Fixed Effect Estimations

\begin{tabular}{|c|c|c|c|c|c|c|}
\hline \multirow[b]{2}{*}{ Variable } & \multicolumn{2}{|c|}{ Model 1} & \multicolumn{2}{|c|}{ Model 2} & \multicolumn{2}{|c|}{ Model 3} \\
\hline & Coefficient & $\begin{array}{l}\text { Standard } \\
\text { Error }\end{array}$ & Coefficient & $\begin{array}{c}\text { Standard } \\
\text { Error }\end{array}$ & Coefficient & $\begin{array}{c}\text { Standard } \\
\text { Error }\end{array}$ \\
\hline $\begin{array}{c}\text { Bilateral } \\
\text { trade } \\
\text { Intensity }\end{array}$ & $\begin{array}{c}8.95 \\
(2.58)^{* *}\end{array}$ & 3.46 & $\begin{array}{c}13.55 \\
(2.89)^{*}\end{array}$ & 4.69 & $\begin{array}{c}18.13 \\
(4.11)^{*}\end{array}$ & $4 \cdot 41$ \\
\hline $\begin{array}{c}\text { Fiscal Policy } \\
\text { Correlation }\end{array}$ & $\begin{array}{c}-0.25 \\
(-3.13)^{*}\end{array}$ & 0.08 & $\begin{array}{c}-0.27 \\
(-3.25)^{*}\end{array}$ & 0.08 & $\begin{array}{c}-0.28 \\
(-3.32)^{*}\end{array}$ & 0.08 \\
\hline $\begin{array}{c}\text { Monetary } \\
\text { Policy } \\
\text { Correlation }\end{array}$ & $\begin{array}{c}0.08 \\
(2.71)^{*}\end{array}$ & 0.08 & $\begin{array}{c}0.20 \\
(2.60)^{* *}\end{array}$ & 0.08 & $\begin{array}{c}0.18 \\
(2.34)^{\star *}\end{array}$ & 0.08 \\
\hline $\begin{array}{c}\text { Exchange } \\
\text { Rate } \\
\text { Variability }\end{array}$ & $\begin{array}{c}0.21 \\
(0.92)\end{array}$ & 0.21 & $\begin{array}{c}0.21 \\
(1.00)\end{array}$ & 0.21 & $\begin{array}{c}0.24 \\
(1.12)\end{array}$ & 0.22 \\
\hline $\begin{array}{l}\text { Industrial } \\
\text { Similarity }\end{array}$ & $\begin{array}{l}-0.26 \\
(0.22)\end{array}$ & 0.22 & $\begin{array}{c}0.23 \\
(-1.08)\end{array}$ & 0.21 & $\begin{array}{c}-0.20 \\
(-0.95)\end{array}$ & 0.21 \\
\hline Within $R^{2}$ & \multicolumn{2}{|c|}{0.48} & \multicolumn{2}{|c|}{0.49} & \multicolumn{2}{|c|}{0.33} \\
\hline
\end{tabular}

*, **, *** show significant at $1 \%, 5 \%$ and $10 \%$ respectively.

The results in the above table show that all three measures of bilateral trade intensity have a positive and highly significant impact on GDP co-movements. It validates the theoretical relationship between them as expressed by Frankel and Rose (1998). The positive sign of the coefficient explains that expansion of bilateral exports leads to a boost in GDP co-movements. Fiscal correlation negatively affects synchronization. It supports the point raised by Clark and Wincoop (2001) that dissimilar fiscal policy may result in higher synchronization of the business cycle. Besides, Pakistan's fiscal policy is highly volatile and it often changes due to political reasons. Therefore, its correlation has a negative impact on GDP synchronization. Monetary Policy correlation has a positive and significant impact on GDP co-movements in all three models. The significance of the variable shows the potentials of enhancing synchronization among trading partners through monetary channel. These results are in line with Shin and Wang (2003). Exchange rate variability has a positive and insignificant impact on output co-movements in all models which indicates that the exchange rate works under the Mundell hypothesis i.e. exchange rate variability is a fluctuations absorber in the model. As expected, Industrial similarity has a negative coefficient which indicates that a big difference in the production structure of countries leads to divergence of the business cycle. These results are consistent with Xing and Abbott (2007) except that industrial similarity is significant in their model.

\subsection{Variance Inflation Factor}

Lastly, VIF is computed to check the multicollinearity among regressors. For measuring this, independent variables are regressed on each other and $\mathrm{R}^{2}$ of that regression is used to compute VIF. The results of VIF are presented in Table 3. 
Review of Economics and Development Studies, Vol. 7 (2) 2021, 231-242

Table 3: VIF Analysis

\begin{tabular}{|c|c|c|}
\hline Variable & VIF $_{\mathbf{i}}$ & $\mathbf{1} / \mathbf{V I F}_{\mathbf{i}}$ \\
\hline FP & 1.22 & 0.83 \\
\hline MP & 1.18 & 0.85 \\
\hline EXCH & 1.02 & 0.98 \\
\hline IS & 1.07 & 0.94 \\
\hline
\end{tabular}

The results show that the values of VIFi are less than 10 which is an indication of the absence of multicollinearity among regressors.

\section{Conclusion and Policy Recommendations}

Bilateral trade intensity appeared as the most important determinant of business cycle. The period average of bilateral trade and business cycle synchronization show that both have improved over time. Business cycle Synchronization has shown an improvement in the trading partners of Pakistan. The results of this study reveal that bilateral trade is beneficial for enhancing business cycle synchronization in major trading partners of Pakistan. It implies that in the modern global world business cycle of a country is under the continuous influence of its trading partners. These results are in line with Frankel and Rose (1998) and Shin and Wang (2003). Economic policies have also come up an important source of converged business cycles. Thus, policymakers can utilize this channel to enhance synchronization.

The negative sign of fiscal coordination indicates that different fiscal stances may help countries in synchronizing their business cycles. The sign of the coefficient of industrial similarity is consistent with the theory buy it is insignificant because the countries included in the sample have diverse industrial structure that become hurdles in the way of improving the BCS.

From the above analysis it can be concluded that bilateral trade and coordination of fiscal and monetary policies are prime sources of converged business cycles. The convergence of business cycles is necessary for developing countries to enhance their economic integration and to reap the full benefits of currency unions. This calls for a need to formulate and implement consistent monetary and fiscal policy policies in these countries.

\section{References}

Antonakakis, N., \& Tondl, G. (2014). Does integration and economic policy coordination promote business cycle synchronization in the EU? Empirica, 41(3), 541-575.

Artis, M., \& Siebert, H. (2004). Is there a European business cycle? Macroeconomic policies in the world economy, 329, 53.

Barrios, S., \& De Lucio, J. J. (2003). Economic integration and regional business cycles: Evidence from the Iberian regions. Oxford Bulletin of Economics and Statistics, 65(4), 497-515.

Böwer, U., \& Guillemineau, C. (2006). Determinants of business cycle synchronisation across euro area countries (No. 587). ECB Working Paper.

Calderón, C., Chong, A., \& Stein, E. (2007). Trade intensity and business cycle synchronization: Are developing countries any different? Journal of International Economics, 71(1), 2-21. https://doi.org/10.1016/j.jinteco.2006.06.001

Camacho, M., \& Perez-Quiros, G. (2006). A new framework to analyze business cycle synchronization. Contributions to Economic Analysis, 276, 133-149. 


\section{Review of Economics and Development Studies, Vol. 7 (2) 2021, 231-242}

Chiquiar, D., \& Ramos-Francia, M. (2004). Bilateral trade and business cycle synchronization: Evidence from Mexico and United States manufacturing industries. Documento de Investigación, 5 .

Clark, T. E., \& Van Wincoop, E. (2001). Borders and business cycles. Journal of International Economics, 55(1), 59-85.

Duval, M. R. A., Cheng, M. K. C., Oh, K. H., Saraf, R., \& Seneviratne, M. (2014). Trade integration and business cycle synchronization: A reappraisal with focus on Asia. International Monetary Fund.

Frankel, J. A., \& Romer, D. H. (1999). Does trade cause growth? American economic review, 89(3), 379-399.

Frankel, J. A., \& Rose, A. K. (1998). The endogenity of the optimum currency area criteria. The Economic Journal, 108(449), 1009-1025.

Gouveia, S., \& Correia, L. (2013). Trade integration and business cycle synchronization in the Euro area: The case of southern European countries. Journal of Economic Integration, 28(1), 85107. https://doi.org/10.11130/jei.2013.28.1.85

Gruben, W. C., Koo, J., \& Millis, E. (2002). How much does international trade affect business cycle synchronization? (Vol. 2). Dallas, TX: Federal Reserve Bank of Dallas.

Imbs, J. (2004). Trade, finance, specialization, and synchronization. The Review of Economics and Statistics, 86(3), 723-734.

Inklaar, R., Jong-A-Pin, R., \& de Haan, J. (2008). Trade and business cycle synchronization in OECD countries-A re-examination. European Economic Review, 52(4), 646-666. https://doi.org/10.1016/j.euroecorev.2007.05.003

Kose, M. A., \& Yi, K. M. (2006). Can the standard international business cycle model explain the relation between trade and co-movement? Journal of International Economics, 68(2), 267295. https://doi.org/10.1016/j.jinteco.2005.07.002

Misztal, P. (2013). International trade and business cycle synchronization in Poland, the European Union and the Euro Zone. Contemporary Economics, 7(3), 65-78. https://doi.org/10.5709/ce.1897-9254.90

Mundell, R. A. (1961). A theory of optimum currency areas. The American economic review, 51(4), 657-665.

Rana, P. B., Cheng, T., \& Chia, W. M. (2012). Trade intensity and business cycle synchronization: East Asia versus Europe. Journal of Asian Economics, 23(6), 701-706. https://doi.org/10.1016/j.asieco.2011.11.003

Ravn, M. O., \& Uhlig, H. (2002). On adjusting the Hodrick-Prescott filter for the frequency of observations. Review of economics and statistics, 84(2), 371-376.

Saiki, A., \& Kim, S. H. (2014). Business Cycle Synchronization and Vertical Trade Integration: A Case Study of the Eurozone and East Asia. SSRN Electronic Journal, 407. https://doi.org/10.2139/ssrn.2376787

Shin, K., \& Wang, Y. (2003). Trade integration and business cycle synchronization in East Asia. Asian Economic Papers, 2(3), 1-20.

Xing, T., \& Abbott, A. (2007, September). The effects of trade, specialisation and financial integration for business cycle synchronisation. In 9th European Trade Study Group Conference (pp. 13-15). 